\title{
Review \\ MECHANICALLY SEPARATED MEAT OF BROILER BREEDER AND WHITE LAYER SPENT HENS
}

\author{
Marco Antonio Trindade ${ }^{1}$; Pedro Eduardo de Felício ${ }^{1}$; Carmen Josefina Contreras Castillo²* \\ ${ }^{1}$ FEA/UNICAMP, Depto. de Tecnologia de Alimentos - C.P. 6011 - 13084-971 - Campinas, SP - Brasil. \\ ${ }^{2}$ USP/ESALQ, Depto. de Agroindústria, Alimentos e Nutrição, C.P. 9 - 13418-900 - Piracicaba, SP - Brasil. \\ *Corresponding author <ccastill@esalq.usp.br>
}

\begin{abstract}
There are aproximately 90 millions of hens housed in Brazil, that concluding their production cycle, become available for slaughter. The poultry industry has economical interest in the use of spent hen meat through adequate processes. This review evaluates the quality of mechanically separated spent hen meat by chemical and functional characteristics, such as proximate composition, colagen, cholesterol, bones, calcium and iron contents, fatty acid profile, $\mathrm{pH}$ and emulsifying capacity, and as raw material for sausage production. The mechanical separation of meat migth be a good alternative use for spent hen carcasses.

Key words: MSM, chemical composition, cholesterol, functional characteristics
\end{abstract}

\section{CARNE MECANICAMENTE SEPARADA DE GALINHAS POEDEIRAS E MATRIZES PESADAS DE DESCARTE}

\begin{abstract}
RESUMO: O Brasil dispõe de aproximadamente 90 milhões de galinhas poedeiras e matrizes pesadas de corte comerciais alojadas, que tornam-se disponíveis para abate ao final do ciclo de postura. Uma melhor utilização da carne de galinhas de descarte, através de processamentos adequados, interessa economicamente para a indústria avícola. Esta revisão avaliou a qualidade da carne mecanicamente separada de galinhas, através de características químicas, nutricionais e de funcionalidade tais como composição centesimal, teores de colágeno, colesterol, ossos, cálcio e ferro, perfil de ácidos graxos, valor de pH ecapacidade de emulsificação, como matéria-prima para a fabricação de embutidos. A separação mecânica da carne pode representar uma boa alternativa para utilização das carcaças destas aves.

Palavras-chave: CMS, composição química, cholesterol, propriedades funcionais
\end{abstract}

\section{INTRODUCTION}

The number of confined hens in Brazil is as large as 60 million commercial egg-layers and 30 million broiler breeders. Broiler breeders produce commercial broilers with high hybrid vigor for meat production. They are heavy birds (3-to-4-kg) with satisfactory amount of meat in the breast and thighs. However, they also have a lot of subcutaneous and abdominal fat. Cornish and Plymouth Rock are basically the two most used breeds of broilers. On the other hand, the white commercial layers are small birds, weighing up to $1.5 \mathrm{~kg}$, with little meat. They are raised apart of males to produce eggs. The most common breed used is the White Leghorn, which produces white eggs.

According to Lyons (2001), the volume of biological material, costs of labor and transportation associated to the slaughtering of laying hens make it one of the main economical and environmental problems of poultry industry. According to the author, there are approximately 320 million confined layers in the U.S.A., which value about US\$2.69 each, 55\% of which are slaughtered annually. At the end of the production cycle, the value per bird is reduced to US\$ 0.07 , and commercial layers and broiler breeders are then normally slaughtered and made available for the production of concentrated broths, domestic consumption in soups and stews. (Ajuyah et al., 1992; VollerReasonover et al., 1997). Farms have difficulty selling these birds with reasonable profit. Grunden et al. (1972) reported that depreciation of hens was the second highest cost in the egg production industry, behind only the cost of the feed. Kondaiah \& Panda (1987) affirm that one of the main needs of poultry farming is the upgrade of spent hens.

Another area for the use of these poultry is the production of sausages, using mechanically separated hen meat (MSHM) (Mott et al., 1982; Lee et al., 1997; Grunden et al., 1972; Jantawat \& Dawson, 1980). Mechanically-separated chicken meat (MSCM) is made from the deboning and cutting of parts with lower commercial value, such as the back and the neck (Barreto, 1995), while the production of MSHM is normally made from the whole carcass. With the objec- 
tive of finding a better use for the carcasses of these birds at the end of the egg laying period, the purpose of this work was to review data available in the literature on the quality of mechanically separated meat of spent hens as raw material for sausages, regarding their chemical composition and functional characteristics.

\section{Mechanically separated meat}

Early deboning or mechanical separation machines were developed for fish in Japan in the late 1940 s, as a result of the need of the fish processing industry of using meat from several species of fish that were underutilized, and the increasing demand for products that could be produced with mechanically separated fish meat. The mechanical separation of poultry began in the late 1950s in the U.S.A, but for different reasons. The consumer preference for chicken cuts instead of whole chicken and, later on, the demand for chicken fillets and convenience products, such as nuggets, hamburgers and marinated cuts, required the finding of ways to use backs, necks, and bones left overs from manual deboning processes. These parts make up about $24 \%$ of the edible part. From there on, the mechanically separated meat of poultry became available and started to be used in the manufacture of several products, such as sausages, bolognas, salamis and dry soups (Field, 1988; Froning, 1981).

In every deboning process, after the removal of the usual meat cuts, there is always an amount of meat which is firmly attached to the bones. Mechanically separated meat is a product resulting from of the mechanical separation of the meats attached to these bones. Normally the mechanical separation is made for bones of irregular shape, more difficult to be manually deboned, such as vertebral column and neck. However, other bones with attached meat, or whole carcasses, can be submitted to mechanical separation.

\section{Chemical composition of mechanically separated poul- try meat}

With the introduction and increasing use of mechanically separated meats in the elaboration of sausages and other industrialized products, many questions arose regarding their nutritional value for human consumption. Studies on the most diversified characteristics of these meats were carried out on contents and quality of proteins, lipids and minerals, bone content, lipid and pigment stability, pathogenic and spoilage bacteria, among others, proved that consumption of MSMs does not jeopardize human health and can prevent the wasting of large amounts of minerals, lipids and animal protein. Next, some aspects of the chemical and nutritional composition of MSMs that can influence their use for the elaboration of sausages will be discussed.

\section{Proximate composition}

Mechanical deboning of poultry affects the proximate composition of resulting meat. Considerable amounts of lipids present in the raw material are incorporated in the MSMs, diluting protein and increasing the lipid contents of the deboned tissues. These lipids include those present in the bone marrow, the subcutaneous fat, the skin and the abdominal fat, excluding the fat of the viscera removed during the slaughtering process. Moreover, the proximate composition can vary according to the settings and type of machine used for the mechanical separation (Froning, 1981).

Table 1 presents the proximate compositions of MSMs from several sources. The lipid content of the MSM is really higher and the protein contents are lower in MSMs in comparison to fillets, where as the protein content is higher, and the lipid content is lower and steadier for MSM of hens than MSM of chicken. It could expect the opposite, since older animals have more fat deposits. However, MSMs of hens are generally extracted from the whole carcasses, and the higher the meat content in the raw material, the lower the amount of fat in the MSM.

Table 1 - Proximate composition of manually deboned hen meat and MSMs of hens and chicken (fresh weight basis).

\begin{tabular}{lccccl}
\hline Raw material & Protein & Fat & Moisture & Ash & References \\
\hline Hen MSM & -15.5 & 19.0 & 63.8 & 1.3 & Hamm \& Young (1983) \\
Hen MSM & 15.4 & 20.4 & 62.5 & 1.2 & Mott et al. (1982) \\
Hen MSM & 14.2 & 26.2 & 60.1 & n.a. & Grunden et al. (1972) \\
Hen MSM & 13.9 & 18.3 & 65.1 & n.a. & Froning (1981) \\
Chicken back w/skin MSM & 8.5 & 30.4 & 60.0 & 0.6 & Pollonio (1994) \\
Chicken back w/ ${ }^{\circ}$ skin MSM & 12.4 & 15.0 & 70.1 & 1.1 & Pollonio (1994) \\
Chicken back and neck MSM & 9.3 & 27.2 & 63.4 & n.a. & Grunden et al.(1972) \\
Chicken back and neck MSM & 13.4 & 14.4 & 72.2 & n.a. & Essary (1979) \\
Hen breast fillets & 23.1 & 3.4 & 72.1 & 1.2 & Kondaiah \& Panda (1987) \\
Hen thigh fillets & 19.5 & 8.8 & 69.9 & 1.0 & Kondaiah \& Panda (1987) \\
\hline
\end{tabular}




\section{Collagen content}

High contents of collagen in any meat can negatively influence its technological and nutritional characteristics, since collagen is a protein with inferior functionality and low nutritional value because of its poor balance of amino acids. However, as collagen is strongly attached to the bones, very little of it goes through the ridges of the deboning machines and, consequently, little collagen is incorporated to MSMs (Field, 1988). Nonetheless Al-Najdawi \& Abdullah (2002) evaluated collagen contents in manually and mechanically deboned meats of whole and skinned hens, and observed higher contents of collagen in the MSMs (3.45 and 3.00\% for whole and skinned carcasses, respectively) in comparison to the meats of manually deboned hens $(1.60$ and $0.85 \%$ for whole and skinned carcasses, respectively).

The content of the amino acid hydroxyproline is an index of the amount of connective tissue in a meat has been considered by several researchers. According to Babji et al. (1980), hydroxyproline contents was higher in the MSM of cooked hen (0.76 g $100 \mathrm{~g}^{-1}$ of tissue) in comparison to the MSM of chicken back and neck

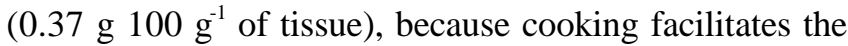
removal of collagen. This report was confirmed by Hamm \& Young (1983) who, next to other raw materials, compared the MSM of raw and cooked hens. There was a small elevation in the content of hydroxyproline for the

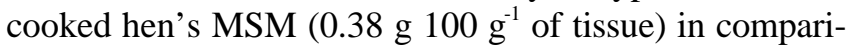

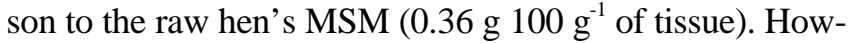
ever, even with this increase, the content of hydroxypro- line was close to that found for the MSM of chicken

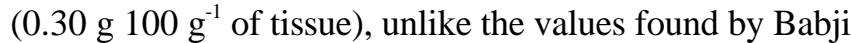
et al. (1980).

\section{Fatty acids Profile}

Amongst the fatty acids profile of meats, the high levels of unsaturated fatty acids are usually associated to poultry. Unsaturated fatty acids are regarded as beneficial to human health. However, they are more prone to oxidation, causing losses in sensorial quality of meats during the storage.

Several authors evaluated the profile of fatty acids in MSMs with the purpose of comparing it to those found in manually deboned meats, according to the incorporation of the lipids of the bone marrow and the skin of the poultry. Mott et al. (1982) compared the MSM of whole hens with the MSM of skinned hens, and found higher concentrations of unsaturated fatty acids in the first. On the other hand, according to Moerck \& Ball (1974), the composition of fatty acids in the marrow and in the MSM of chichen was similar to that of the breast, thigh and skin. Jantawat \& Dawson (1980) compared mechanically and manually deboned hen meats, and also found very close fatty acids profiles, as shown in Table 2.

\section{Cholesterol content}

A potencial aspect of concern by consumers is the cholesterol content, which is higher in MSMs than in manually separated meats as a result of the inclusion of the bone marrow material, which has high cholesterol concentrations. Ang \& Hamm (1982) analyzed cholesterol

Table 2 - Fatty acids profile of mechanically separated meats of chicken and hens and in meat of hen breasts.

\begin{tabular}{|c|c|c|c|c|c|c|}
\hline \multirow{2}{*}{ Fatty acids } & \multirow{2}{*}{ MSM hens w/skin ${ }^{1}$} & \multirow{2}{*}{ MSM hens ${ }^{2}$} & \multicolumn{2}{|c|}{ Light hen meat ${ }^{3}$} & \multicolumn{2}{|c|}{ Dark hen meat ${ }^{3}$} \\
\hline & & & $\mathrm{MSM}^{4}$ & Manual ${ }^{5}$ & $\mathrm{MSM}^{6}$ & Manual $^{7}$ \\
\hline & $-\cdots-1$ & $\%$ & the tota & fatty acid & $-\cdots$ & - \\
\hline \multicolumn{7}{|l|}{ Saturated } \\
\hline Lauric C12:0 & - & - & 1.6 & 1.6 & 1.2 & 1.6 \\
\hline Miristic C14:0 & 1.1 & 0.9 & 2.2 & 2.8 & 2.5 & 2.8 \\
\hline Palmitic C16:0 & 26.3 & 21.2 & 23.3 & 21.4 & 20.7 & 17.4 \\
\hline Stearic C18:0 & 4.4 & 4.1 & 7.5 & 10.4 & 8.4 & 11.5 \\
\hline TOTAL SATURATED & 31.8 & 26.2 & 34.6 & 36.2 & 32.8 & 33.3 \\
\hline \multicolumn{7}{|l|}{ Monounsaturated } \\
\hline Palmitoleic C16:1 & 7.1 & 5.4 & 5.7 & 6.8 & 7.4 & 10.1 \\
\hline Oleic C18:1 & 41.8 & 45.5 & 34.9 & 32.7 & 32.7 & 28.5 \\
\hline \multicolumn{7}{|l|}{ Polyunsaturated } \\
\hline Linoleic C18:2 & 19.3 & 22.1 & 23.2 & 22.4 & 25.4 & 25.5 \\
\hline Linolenic C18:3 & $\operatorname{Tr}$ & 0.8 & 1.5 & 1.9 & 1.7 & 2.5 \\
\hline Arachidic C20:4 & - & - & $\operatorname{Tr}$ & $\operatorname{Tr}$ & $\operatorname{Tr}$ & $\operatorname{Tr}$ \\
\hline TOTAL UNSATURATED & 68.2 & 73.8 & 65.3 & 63.8 & 67.2 & 66.6 \\
\hline
\end{tabular}

${ }^{1}$ Mott et al. (1982): MSM of spent layers without skin; ${ }^{2}$ Mott et al. (1982): MSM of whole carcasses of spent layers; ${ }^{3} \mathrm{Jantawat} \&$ Dawson (1980); ${ }^{4}$ MSM gotten from the keel of hen breasts; ${ }^{5}$ Fillet manually deboned hen breasts; ${ }^{6} \mathrm{MSM}$ ofhen back and neck; ${ }^{7} \mathrm{Manually} \mathrm{deboned}$ thighs and wings meat

Sci. Agric. (Piracicaba, Braz.), v.61, n.2, p.234-239, Mar./Apr. 2004 
contentsin manually separated chicken meats from the same cuts. Amongst the MSMs, they compared the neck with and without skin and the whole entire back. The results showed that there was a lower cholesterol content in the manually deboned meats than in the respective MSMs (Table 3). The same authors analyzed cholesterol contents in bone marrow (1992 mg $\left.100 \mathrm{~g} \mathrm{~g}^{-1}\right)$ and in the fat of the back (312 mg $100 \mathrm{~g}^{-1}$ ), having indicated that the cholesterol comes both from the marrow and the fat.

The cholesterol contents in breast and thighs of hens were analyzed by Jantawat \& Dawson (1980), who reported that meats from manually deboned hens also presented lower cholesterol contents (43 and 70 mg cholesterol $100 \mathrm{~g}^{-1}$ sample of breast and thigh) than their respective MSMs (73 and $110 \mathrm{mg}$ cholesterol $100 \mathrm{~g}^{-1}$ sample of breast and thigh). That is, cholesterol levels in MSMs, although higher than those of manually deboned meats from the same cuts, are not very high in comparison to the contents of bone marrow or fat.

\section{Calcium and bone particle contents}

Consumers defense groups were concerned about the inclusion of bone fragments in the MSMs (Froning, 1981). The bone particles of MSMs are totally solubilized in $\mathrm{HCl}$ solutions at concentrations similar to the ones found in the stomach (Field, 1988). After the analysis of several studies, this author concluded that mechanically deboned red meat, poultry and fish presented bone fragments in MSMs which were not hazardous to consumers. However, the calcium content was considered possibly too high $(37 \%$ of the bone content of poultry and red meat producer animals) and harmful to health.

Calcium contents found in MSM of pork, poultry and beef ranged from $0.06 \%$ to $0.28 \%$ (Koolmes et al., 1986). These levels are below the maximum limits considered by regulating standards of Brazilian (1.5\% in dry matter), American $(0.75 \%$, equivalent to $3-4 \%$ of bones), and the Dutch $(0.25 \%$ of calcium and $1 \%$ of bones), for instance. The Committee on Calcium Requirements of FAO/WHO recommends the intake of 400-500 mg day ${ }^{-1}$, which means about $200 \mathrm{~g}$ of MSM day ${ }^{-1}$ of a MSM containing $0.25 \%$ of calcium. Except for a few calcium hyper-absorbing individuals, the calcium from MSM can be a nutritional benefit.

Table 3 - Cholesterol contents of manually and mechanically deboned chicken meats ${ }^{1}$.

\begin{tabular}{lcc}
\hline & \multicolumn{2}{c}{ Cholesterol } \\
\cline { 2 - 3 } & Mechanical deboning & Manual deboning \\
\hline & ----- mg $100 \mathrm{~g}^{-1}$ & sample \\
Neck without skin & 94 & 75 \\
Neck with skin & 109 & 94 \\
Back & 95 & 81 \\
\hline
\end{tabular}

${ }^{1}$ Ang \& Hamm (1982)
The calcium content has generally been used as a measure of the bone content in MSMs. Ang \& Hamm (1982) found much higher calcium contents $(53-91 \mathrm{mg}$ $100 \mathrm{~g}^{-1}$ sample) in MSMs from different cuts (chicken neck, with and without skin, and back) than in manually deboned meats from the same cuts (17-34 mg $100 \mathrm{~g}^{-1}$ sample). Grunden et al. (1972) reported that the MSM from whole carcasses of spent layers presents higher calcium contents than the MSM from chicken backs and necks, and turkey backs. Recently, Al-Najdawi \& Abdullah (2002) evaluated the mineral contents of several manually and mechanically deboned meats of whole or skinned hens and found much higher calcium contents in the MSMs (162.5 and $230.0 \mathrm{mg} 100 \mathrm{~g}^{-1}$ of whole and skinned carcasses, respectively) in comparison to manually deboned hens (16.75 and $13.50 \mathrm{mg} 100 \mathrm{~g}^{-1}$ of whole and skinned carcasses, respectively).

The determination of bones (or calcium content) in MSM is a form of controlling the yield of mechanical separation processes. A high bone content means that the pressure used in the deboning process was too high or that the meat to bone ratio was too low (Beraquet, 2000).

The size of the bone particles is determined by the size of the mesh of the deboning "sieve". The Brazilian legislation (Brasil, 2000) establishes that $98 \%$ of bone particles must have a maximum size of $0.5 \mathrm{~mm}$ and maximum width of $0.85 \mathrm{~mm}$. Koolmes et al. (1986) found that between 84.8 and $97.5 \%$ of bone particles of MSMs obtained through different deboning machines were smaller than $1.0 \mathrm{~mm}$.

\section{Technological aspects}

The main use of the MSM, a soft texture material, is in the production of a meat batter as, sausages and Mortadella. In annexes II, III and IV of Normative Instruction $n^{\circ}$. 04, of March 31, 2000 (Brasil, 2000), the Technical Regulations of the Identity and Quality of Mortadella and sausages were approved, establishing the limits to the addition of MSM. Table 4 presents data on some of the characteristics of the products for which the use of MSM is allowed. This regulation allows the use of up to $60 \%$ of MSM in substitution of the meat raw material in some types of emulsified sausages. The problem with the use of large ratios of MSM in meat products is the low stability of this raw material, which is very prone to lipid and pigment oxidation as well as microbial growth.

In addition to the protein and fat contents, some technological aspects, such as $\mathrm{pH}$, water holding capacity and emulsifying capacity, are the main factors affecting the technological quality of MSM. The functionality of myofibrillar proteins determines the quality of the meat emulsion formed, mainly regarding the texture, the yield of the process, and the emulsion stability. However, oxidized lipids, which can be present in the MSMs, can cause 
Table 4 - Some Identity and Quality Characteristics of Meat Products containing MSM.

\begin{tabular}{lcccc}
\hline Products & Humidity $^{1}(\max )$. & Fat $^{1}(\max )$. & Calcium $^{2}(\max )$. & MSM $^{3}\left(\max ^{\prime}\right)$ \\
\hline Bologna & 65 & 30 & 0.9 & 60 \\
Bologna & 65 & 30 & 0.3 & 20 \\
Poultry bologna & 65 & 30 & 0.6 & 40 \\
Cooked sausages & 60 & 30 & 0.3 & 60 \\
Sausages & 65 & 30 & 0.9 & 60 \\
Vienna or Frankfurt Sausages & 65 & 30 & 0.9 & 60 \\
Poultry sausage & 65 & 30 & 0.6 & 40 \\
Cooked hamburger & --- & 23 & 0.45 & 30 \\
Cozida meat balls & --- & 18 & 0.45 & 30 \\
\hline
\end{tabular}

Source: Beraquet (2000)

${ }^{1}$ Fresh weight basis; ${ }^{2}$ Dry weight basis; ${ }^{3}$ Mechanically separated meat of (animal species)

protein polymerization and insolubilization, polypeptide chain rupture, amino acid destruction, and formation of products with protein addition. These interactions influence negatively the functional properties of the meat. The higher the instability of the material in regard to lipid oxidation, as in the case of the MSMs, the greater the effects on the functionality. In systems with high water activity or aqueous solution, proteins form crossed links among themselves in the presence of peroxidized lipids, with simultaneous loss of solubility. Reactions between malonaldehyde, a by-product of the lipid oxidation, and free amino groups of proteins, lead to the formation of irreversible covalent links, with a consequent loss of the solubility of proteins (Pollonio, 1994).

\section{Hydrogenionic potencial ( $\mathrm{pH})$}

Generally, MSMs present higher $\mathrm{pH}$ than manually deboned meats, in general as a result of the incorporation of red marrow, in wich $\mathrm{pH}$ ranges from 6.8to 7.4 (Field, 1988). According to Beraquet (2000), the pH of manually deboned meat lies between 5.8 and 5.9 for the breast and 6.2 and 6.3 for the thigh, whereas MSMs have values between 6.5 and 7.0. These high $\mathrm{pH}$ values favor the water holding capacity, but, on the other hand contribute to the increase in the bacterial load, speeding up the spoilage process.

\section{Water holding capacity (WHC)}

This property is related to the weight loss and final quality of the product in which the MSM is used, as a result of the formulation, processing, storage, cooking and freezing. The MSM increases the WHC of the products, for it has a higher $\mathrm{pH}$ than the manually deboned meats. Calcium, magnesium, iron and copper decrease the WHC. The presence of the conjunctive tissue, in which the main protein is collagen, makes the WHC decrease when heated at temperatures of $60-65^{\circ} \mathrm{C}$, causing shrinking, deficient skinning, unstable emulsions, gel formations and wrinkling of the external skin of the emulsified products. Freezing decreases the WHC of the MSM, especially when done slowly (Field, 1988).

\section{Emulsifying capacity}

MSMs have been widely used in the emulsified sausages production. Therefore, the emulsification capacity is an important attribute of these meats. The determination of this functional property generally follows the methodology described by Swift et al. (1961), based in the amount of oil that a meat is able to emulsify. The values are generally expressed in $\mathrm{mL}$ of oil per $2.5 \mathrm{~g}$ of meat. Variations in the emulsifying capacity of a MSM may result from its composition, quality and amount of proteins, protein denaturation, freezing and storage. The content of fat in MSM is the main factor that affects its capacity of emulsification.

Froning et al. (1973) studied the influence of the skin content of MSM on several functional properties and observed that as there was an increase in the addition of skin to the carcasses $(0 ; 16.8 ; 28.9$ and $38.9 \%)$ before the mechanical separation, there was a proportional increase in the content of fat in MSM $(15.3 ; 24.6 ; 29.8$ and $33.6 \%$ ), and a reduction in the emulsifying capacity (182, 148,133 and $127 \mathrm{~mL}$ oil $\left.2.5 \mathrm{~g}^{-1} \mathrm{MSM}\right)$. The increase in the skin level did not cause a significant increase in the collagen content of the MSMs.

Regarding the proteins quality, McMahon \& Dawson, quoted by Froning (1981), determined the soluble protein content in manually and mechanically deboned turkey meat. The percentage of these proteins was lower in the MSM than in the manually deboned meat. The emulsifying capacity was higher in the manually deboned meat but, on the other hand, the MSM presented greater water holding capacity.

\section{Sensorial quality of sausages made with hen MSM}

In general, differences in the flavor (aroma and taste) of products added up to $20 \%$ of MSM are not noticed, making them even more acceptable at times for being softer and juicier. However, with storage, the change in the flavor is more quickly detected than in products with no addition of MSM. This change has been described as a residual flavor of liver and has been attributed to the marrow. 
Baker et al. (1984) carried out a sensorial evaluation of the global acceptance in a 9-point scale $(9=$ excellent and $1=$ poor) for hamburgers elaborated with manually deboned meat of chicken thigh (GrTh) and mechanically separated Leghorn hens meat (MDSL), and reported that the sensorial panel rated 7.0; 6.0 and 5.2 the products elaborated with $100 \% \mathrm{GrTh}, 50 \% / 50 \% \mathrm{GrTh} / \mathrm{MDSL}$ and 100\% MDSL, respectively. Angel (1987) compared a sausage elaborated with 100\% MSM from whole carcasses of egg layers to sausages of two commercial brands, using a 9-point scale $(1=\mathrm{I}$ extremely liked it, and $9=\mathrm{I}$ extremely disliked it). The two commercial brands were rated 2.65 and 3.42, whereas the sausage with $100 \%$ MSM was rated 4.02 , which is within the acceptability limits and very close to the two commercial brands.

As to the texture, products with over $30 \%$ of MSM are generally considered to present graininess (Field, 1988), due to bone particles. When MSM of whole carcasses of hens is used, these particles are mainly from thighs, which are highly calcified and break into small particles during the grinding in the deboning machine and are incorporated to the MSM (Grunden \& Mac Neil, 1973).

\section{REFERENCES}

AJUYAH, A.O.; HARDIN, T.R.; CHEUNG, K.; SIM, J.S. Yield, lipid. cholesterol and fatty acid composition of spent hens fed full-fat oil seeds and fish meal diets. Journal of Food Science, v.57, p.338-341, 1992.

AL-NAJDAWI, R.; ABDULLAH, B. Proximate composition, selected minerals, cholesterol content and lipid oxidation of mechanically and hand-deboned chickens from the Jordanian market. Meat Science, v.61, p.243-247, 2002.

ANG, C.Y.W.; HAMM, D. Proximate analyses, selected vitamins and minerals and cholesterol content of mechanically deboned and handdeboned broiler parts. Journal of Food Science, v.47, p.885-888, 1982.

BABJI, A.S.; FRONING, G.W.; SATERLLE, L.D. Protein nutritional quality of mechanically deboned poultry meat as predict by de C-PER assay. Journal of Food Science, v.45, p.441-443, 1980.

BAKER, R.C.; O'BRIEN, S.W.; GOSSET, P.W. Development and evaluation of chickenburger formulations and effect of beating time incorporating underutilized poultry meats. Poultry Science, v.63, p.938948, 1984.

BARRETO, G. Caracterização microbiológica, sensorial e nutricional de lingüiça congelada contendo carne de frango mecanicamente separada. Campinas: FEA/UNICAMP, 1995. 108p. (Dissertação - Mestrado).

BERAQUET, N.J. Carne mecanicamente separada de aves. In: SEMINÁRIO E CURSO TEÓRICO-PRÁTICO “AGREGANDO VALOR À CARNE DE AVES”. Campinas, 2000. Campinas: CTC, ITAL, 2000.

BRASIL. Ministério da Agricultura e Abastecimento. Secretaria de Defesa Agropecuária. Regulamento técnico para fixação de identidade e qualidade de carne mecanicamente separada (CMS) de aves, bovinos e suínos. Diário Oficial, 05 abr. 2000. p.6-7. Instrução Normativa, 4 Anexo 1.
ESSARY, E.O. Moisture, fat, protein and mineral content of mechanically deboned poultry meat. Journal of Food Technolology, v.44, p.10701073, 1979.

FIELD, R.A. Mechanically separated meat, poultry and fish. In: PEARSON, A.M.; DUTSON, T.R. (Ed.) Edible meat by-products. New York: Elsevier Applied Science, 1988. p.83-128.

FRONING, G.W. Mechanical deboning of poultry and fish. Advances in Food Research, v.27, p.109-147, 1981.

FRONING, G.W.; SATERLLE, L.D.; JOHNSON, F. Effect of skin content prior to deboning on emulsifying and color characteristics of mechanically deboned chicken back meat. Poultry Science, v.52, p.923926, 1973.

GRUNDEN, L.P.; MAC NEIL, J.H. Examination of bone content in mechanically deboned poultry meat by EDTA and atomic absortion spectrophotometric methods. Journal of Food Science, v.38, p.712713, 1973.

GRUNDEN, L.P.; MAC NEIL, J.H.; DIMICK, P.S. Poultry product quality: chemical and phisical characteristics of mechanically deboned poultry meat. Journal of Food Science, v.37, p.247-249, 1972.

HAMM, D.; YOUNG, L.L. Further studies on the composition of commercially prepared mechanically deboned poultry meat. Poutry Science, v.62, p.1810-1815, 1983.

JANTAWAT, P.; DAWSON, L.E. Composition of lipids from mechanically deboned poultry meats and their composite tissues. Poultry Science, v.59, p.1043-1052, 1980.

KONDAIAH, N.; PANDA, B. Physico-chemical and functional properties of spent hen components. Journal of Food Science and Technology India, v.24, p.267-269, 1987.

KOOLMES, P.A.; BUCKER, P.G.; VAN LOGTESTUN, J.G.; TUINSTRAMERLGERS, J. Histometrical and chemical analysis of mechanically deboned pork, poultry and veal. Journal of Animal Science, v.63, p.1830, 1986.

LEE, T.G.; WILLIAMS, S.K.; SOLAN, D.; LITTELL, R. Development and evaluation of a chicken beakfast sausage manufactured with mechanically deboned chicken meat. Poultry Science, v.76, p.415-421, 1997.

LYONS, J.J. Spent hen utilization. In: 2001 MIDWEST POULTRY FEDERATION EGG PRODUCTION WORKSHOP, ST. PAUL, 2001.

MECHANICALLY DEBONED RED MEAT, POULTRY AND FISH. Food Trade Review, v.50, p.66-68, 1980.

MOERCK, K.E.; BALL JR., H.R. Lipid autoxidation in mechanically deboned chicken meat. Journal of Food Science, v.39, p.876-879, 1974.

MOTT, E.L.; MACNEIL, J.H.; MAST, M.G.; LEACH, R.M. Protein efficiency ratio and amounts of selected nutrients in mechanically deboned apent layer meat. Journal of Food Science, v.47, p.655-656, $663,1982$.

POLLONIO, M.A.R. Estudo das propriedades funcionais das proteínas miofibrilares e oxidação lipídica de carne de frango mecanicamente desossada. Campinas: FEA/UNICAMP, 1994. 141p. (Tese - Doutorado).

SWIFT, C.E.; LOCKETT, C.; FRYAR, A.J. Comminuted meat emulsions The capacity of meat for emulsifying fat. Food Technology, v.15, p.468473, 1961.

VOLLER-REASONOVER, L.; HAN, I.Y.; ACTON, J.C., TITUS, T.C.; BRIDGES, W.C.; DAWSON, P.L. High Temperature processing effects on the properties of fowl meat gels. Poultry Science, v.76, p.774-779, 1997.

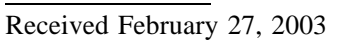

Accepted November 14, 2003 